\title{
Major membrane proteins and lipoproteins as highly variable immunogenic surface components and strain-specific antigenic markers of Mycoplasma arthritidis
}

\author{
Martina Droesse, ${ }^{1}$ Gerhard Tangen, ${ }^{1}$ Iris Gummelt, ${ }^{1}$ Helga Kirchhoff, ${ }^{1}$ \\ Leigh R. Washburn ${ }^{2}$ and Renate Rosengarten ${ }^{1} \dagger$
}

Author for correspondence: Renate Rosengarten. Tel: +972 2758176. Fax: +972 2757413.

1 Institut für Mikrobiologie und Tierseuchen, Tierärztliche Hochschule Hannover, Bischofsholer Damm 15, 30173 Hannover, Germany

2 Department of Microbiology, University of South Dakota School of Medicine, 414 East Clark Street, Vermillion, SD 57069-2390, USA

\begin{abstract}
Surface antigenic variation was investigated in Mycoplasma arthritidis, an agent that produces chronic arthritis in rats which shares several features with many mycoplasma-induced diseases and thus defines a well-characterized model system. Hyperimmune rabbit antisera (anti-ISR1, anti-PG6, anti-H606 and anti-158p10) to whole $M$. arthritidis organisms were used as immunological probes in Western immunoblots of four $M$. arthritidis prototype strains (ISR1, PG6, H606 and D263) and five rat-passaged substrains (ISR1p1, ISR1p7, ISR1p8, 158 p10 and D263p1). Several prominent antigens were identified that varied in expression. By Triton X-114 phase fractionation and treatment of whole cells with trypsin and carboxypeptidase $Y$, these strain-variant antigens were shown to be integral membrane proteins with C-termini and portions of the polypeptide chains oriented outside the membrane. Western blot immunoscreening of a large number of randomly selected clonal isolates and well-established clonal lineages from stock cultures of $\boldsymbol{M}$. arthritidis ISR1p7, 158p10, PG6 and $\mathrm{H} 606$ revealed an expanded repertoire of variant membrane proteins whose expression was subject to independent, reversible phase variation. Colony immunoblots of these clonal populations with a hyperimmune rabbit antiserum to a gel-purified variant membrane protein (P36) showed that this phase switching occurred at a high frequency $\left(10^{-4}\right.$ to $10^{-2}$ per generation). Detailed immunological and biochemical characterization of the phase-variant membrane proteins demonstrated that they are: (i) antigenically related or distinct; (ii) apparently specific to particular strain populations; (iii) proteins or lipoproteins; (iv) major immunogens of $\boldsymbol{M}$. arthritidis, recognized by serum antibodies from convalescent rat; and (v) able to undergo variation in expression during in vivo passage. Thus, $M$. arthritidis possesses a complex system capable of creating large repertoires of cell surface phenotypes which may affect the multiple interactions of this organism with its host and dictate its potential as a successful infectious agent and pathogen.
\end{abstract}

Keywords: Mycoplasma artbritidis, variable membrane proteins, surface antigenic variation, arthritis

\section{INTRODUCTION}

Several species of mycoplasmas are well-established pathogens, causing diseases in man and other animals
(Tully \& Whitcomb, 1979; Krause \& Taylor-Robinson, 1992; Simecka et al., 1992). These diseases typically involve arthritis, respiratory or genitourinary infections, and often show immunopathological features and

† Present address : Department of Membrane and Ultrastructure Research, The Hebrew University-Hadassah Medical School, PO Box 12272, Jerusalem 91120, Israel.

Abbreviations: pAb, polyclonal antibody; TX-114, Triton X-114. 
sequelae characteristic of chronic disease (Cole et al., 1985a, b). Although several reports have indicated the possible role of antigenic mimicry, modulation of the immune response, nonspecific stimulation of $\mathrm{T}$ and $\mathrm{B}$ lymphocytes and induction of autoantibodies as factors contributing to the disease process (Cole et al., 1985a,.b; Kirchhoff et al., 1989), the actual molecular mechanisms underlying mycoplasma pathogenesis have remained largely elusive. In particular, it has been difficult to envisage how organisms lacking the protection of a rigid cell wall, and apparently with few exceptions, the ability to survive intracellularly, could escape rapid destruction by the host defence mechanisms. The recent discovery of surface antigenic variation in many pathogenic mycoplasma species, including Mycoplasma pulmonis (Watson et al., 1988), M. byorbinis (Rosengarten \& Wise, 1990, 1991; Yogev et al., 1991), Ureaplasma urealyticum (Watson et al., 1990; Zheng et al., 1992), M. bominis (Olson et al., 1991 a), M. fermentans (Wise et al., 1993; Theiss et al., 1993), $M$. gallisepticum (Markham et al., 1993; Yogev et al., 1994) and M. bovis (Rosengarten et al., 1994; Behrens et al., 1994) has provided some insight into how this might be achieved. However, for neither these species, nor for any other mycoplasmas in which variable surface antigens have been identified, has it been unequivocally demonstrated whether the main function of this surface variation is indeed immune evasion and/or whether different antigenic or structural versions of such components are involved in different steps of mycoplasma-host interactions essential to pathogenesis.

Mycoplasma arthritidis appears ideally suited for a research effort to resolve some of these questions. It is a naturally occurring arthritogen of rats and mice (Cole \& Ward, 1973) that has previously been demonstrated to show antigenic differences among strains (Washburn \& Hirsch, 1990; Stadtländer \& Watson, 1992; Washburn et al., 1995). Experimentally-induced $M$. artbritidis arthritis exemplifies the prominent features associated with many mycoplasma infections (Cole et al., 1985a, b) and is therefore widely used as model for studying pathogenic mechanisms (Kirchhoff et al., 1983a, b, 1984, 1989; Washburn \& Ramsey, 1989; Washburn et al., 1993; Cole \& Griffiths, 1993). Since this model is well characterized and easy to manipulate, its use should help increase understanding of the biological functions of mycoplasma antigenic variation and its possible relationship to natural disease. With these aims in mind, the present study was undertaken in order (i) to identify and characterize variable surface antigens of $M$. artbritidis, (ii) to determine their distribution among strains and (iii) to assess the key features of surface antigenic variation in this species. Our results demonstrate that this is accomplished by phase variation and combinatorial expression of multiple abundant membrane-associated proteins and lipoproteins, most of which appear to be strain-specific.

\section{METHODS}

Mycoplasmas and culture conditions. Nine $M$. artbritidis strains and rat-passaged substrains were used in this study. Their origin and sources are listed in Table 1. While strains and substrains D263, ISR1, ISR1p1, ISR1p7, ISR1p8 and 158p10 are highly arthritogenic for rats, strains PG6 and H606 are avirulent (Golightly-Rowland et al., 1970; Kirchhoff et al., 1983a; Washburn \& Ramsey, 1989 ; Binder et al., 1990b; Droesse et al., 1994). The virulence of substrain D263p1 has not been examined. All strains and substrains were propagated at $37^{\circ} \mathrm{C}$ in a modified standard mycoplasma broth medium supplemented with $20 \%(\mathrm{v} / \mathrm{v})$ heat-inactivated horse serum (Rosengarten $e t$ al., 1994). Stocks of strains and substrains were prepared from $72 \mathrm{~h}$ (mid-exponential phase) cultures and stored at $-80^{\circ} \mathrm{C}$. For subcloning, metabolic labelling, detergent phase fractionation, SDS-PAGE, Western immunoblotting and enzyme digestion experiments, frozen stocks were thawed, and $100 \mu \mathrm{l}$ aliquots were inoculated into $1 \mathrm{ml}$ broth cultures.

Subcloning and generation of clonal lineages. Subclones of $M$. artbritidis ISR1p7, 158p10, PG6 and H606 were obtained and screened for expression of variable antigens as previously described (Rosengarten \& Wise, 1990, 1991; Rosengarten et al., 1994). Briefly, fresh broth-grown organisms from primary passages of stocks were serially diluted in broth medium and plated on solid mycoplasma standard medium containing $1 \%$ (w/v) agar (Rosengarten et al., 1994). Plates were incubated at $37^{\circ} \mathrm{C}$ in a moist atmosphere with $5 \%(\mathrm{v} / \mathrm{v}) \mathrm{CO}_{2}$ for $6 \mathrm{~d}$. Wellseparated colonies either randomly selected or displaying variant surface antigen expression as determined by colony immunoblotting (see below) were picked with Pasteur pipettes as agar plugs. These were dispensed into $1 \mathrm{ml}$ broth medium and incubated at $37^{\circ} \mathrm{C}$ for $72 \mathrm{~h}$ until mid-exponential growth phase. Each of these cultures contained approximately $3.3 \times 10^{8}$ c.f.u. $\mathrm{ml}^{-1}$, representing an estimated 28 total generations from the single organism originally plated. They were stored at $-80^{\circ} \mathrm{C}$ and used as stocks for further experiments (see below). Samples of these cultures were subsequently plated to obtain secondgeneration subclones by the same method. Continuous selection of successive subclones provided clonal lineages derived from a single organism. Frequencies of altered expression of specific antigens were determined by dividing the fraction of colonies which displayed the alternate phenotype by the total generations propagated at the time of plating.

Labelling of mycoplasmas. $M$. artbritidis strains, substrains and clonal subpopulations were labelled with $\mathrm{L}-\left[{ }^{35} \mathrm{~S}\right]$ cysteine (specific activity $1210 \mathrm{Ci} \mathrm{mmol}^{-1}, 44.8 \mathrm{TBq} \mathrm{mmol}^{-1}$; Du Pont) or $9,10-\left[{ }^{3} \mathrm{H}\right]$ palmitic acid (specific activity $60 \mathrm{Ci} \mathrm{mmol}^{-1}$, $2.2 \mathrm{TBq} \mathrm{mmol}^{-1}$; Du Pont), using methods previously described in detail (Behrens et al., 1994).

Antibodies. Five polyclonal antisera (pAbs) generated in female New Zealand White rabbits were used for immunostaining; they are designated herein as follows. (i) pAb anti-ISR1 (Kirchhoff et al., 1983a) and (ii) pAb anti-158p10 were prepared against whole broth-grown cells of $M$. artbritidis strain ISR 1 and substrain $158 \mathrm{p} 10$, respectively, according to the protocol of Morton \& Roberts (1967), as recently described (Rosengarten t al., 1994). The preparation and characteristics of (iii) pAb antiPG6 to $M$. artbritidis strain PG6 and (iv) pAb anti-H606 to strain H606 have been previously described in detail (Washburn et al., 1985, 1988; Washburn \& Hirsch, 1990). (v) pAb anti-P36 to gelpurified P36 isolated from a clonal variant of $M$. arthritidis substrain ISR1p7 was prepared as follows. To obtain purified P36, $600 \mu \mathrm{g}$ of whole-cell proteins from a late-exponential-phase culture of ISR $1 \mathrm{p} 7 \mathrm{cl} \cdot 1-4.5 \cdot 1.3 .1 .4 .1$ were applied to a $120 \mathrm{~mm}$ channel of a $1.5 \mathrm{~mm}$ SDS $(9 \%, \mathrm{w} / \mathrm{v})$ polyacrylamide slab gel containing $3 \%(\mathrm{w} / \mathrm{v})$ urea (see below). The exact position of the P36 band was visualized by immunoblotting (see below) a small portion of the gel with pAb anti-PG6, while the major portion of the gel was stored at $4^{\circ} \mathrm{C}$. The $\mathrm{P} 36$ band was excised from the gel and eluted with an electro-eluter (model 422; Bio-Rad). Gel 
Table 1. $M$. arthritidis strains and rat-passaged substrains

\begin{tabular}{|c|c|c|c|}
\hline $\begin{array}{l}\text { M. arthritidis } \\
\text { strain/ } \\
\text { substrain* }\end{array}$ & Origin & Source & Reference \\
\hline ISR1 & Rat (internal ear) & $\begin{array}{l}\text { G. Laber, Vienna, } \\
\text { Austria }\end{array}$ & Laber et al. (1975) \\
\hline ISR1p1 & $\begin{array}{l}\text { Rat (subutaneous } \\
\text { abscess) }\end{array}$ & & \\
\hline ISR $1 \mathrm{p} 7$ & $\left.\begin{array}{l}\text { Rat (subcutaneous } \\
\text { abscess) }\end{array}\right\}$ & SVMH‡ & Kirchhoff et al. (1983a) \\
\hline ISR1p8 & Rat (joint) J & & \\
\hline 158p10† & $\begin{array}{l}\text { Rat (subcutaneous } \\
\text { abscess) }\end{array}$ & $\begin{array}{l}\text { B. C. Cole, Salt } \\
\text { Lake City, UT, USA }\end{array}$ & $\begin{array}{l}\text { Golightly-Rowland } \\
\text { et al. (1970) }\end{array}$ \\
\hline PG6 & Rat (joint) & $\begin{array}{l}\text { P. C. T. Hannan, } \\
\text { Betchworth, Surrey, } \\
\text { UK }\end{array}$ & Preston (1942) \\
\hline H606 & Mouse (tumour) & $\begin{array}{l}\text { P. C. T. Hannan, } \\
\text { Betchworth, Surrey, } \\
\text { UK }\end{array}$ & Cahill et al. (1971) \\
\hline $\begin{array}{l}\mathrm{D} 263 \\
\mathrm{D} 263 \mathrm{p} 1\end{array}$ & $\left.\begin{array}{l}\text { Swine (joint) } \\
\text { Rat (joint) }\end{array}\right\}$ & SVMH & Binder et al. (1990a) \\
\hline
\end{tabular}

* The suffixes $\mathrm{p} 1, \mathrm{p} 7, \mathrm{p} 8$ and $\mathrm{p} 10$ designate the number of rat passages.

†The original strain 158 derived from strain Campo (Cole et al., 1967) isolated from the human urogenital tract (Dienes \& Madoff, 1953).

$\ddagger$ SVMH, School of Veterinary Medicine (Institute for Microbiology and Infectious Diseases of Animals), Hannover, Germany.

slices were placed in the glass tubes of the apparatus and eluted overnight at $10 \mathrm{~mA}$ in SDS-PAGE electrode buffer $(192 \mathrm{mM}$ glycine, $25 \mathrm{mM}$ Tris, $0 \cdot 1 \%$ SDS, $\mathrm{pH} 8 \cdot 3$ ). The protein was collected after anodic migration in a membrane cap which contained a dialysis membrane with a $12-15 \mathrm{kDa}$ molecular mass cut-off (Bio-Rad). The isolated P36 was monitored for purity by immunoblotting with pAb anti-PG6 after SDSPAGE. For immunization, an eluted suspension containing purified P36 was prepared as a 1:1(v/v) emulsion with complete Freund's adjuvant (Difco) and injected subcutaneously (on days 0 and 21). One week after the second injection, the rabbit was exsanguinated under pentobarbital anaesthesia, and the serum was divided into equal portions and stored at $-20^{\circ} \mathrm{C}$. For immunostaining of colony blots, all five rabbit $\mathrm{pAbs}$ were diluted 1:1000 in phosphate-buffered saline (PBS: $2.7 \mathrm{mM} \mathrm{KCl}$,

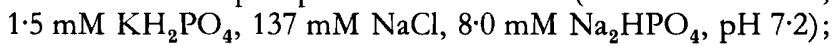
for immunostaining of Western blots, they were diluted $1: 1000$ in PBS containing $0 \cdot 1 \%(\mathrm{v} / \mathrm{v})$ Tween 20 (PBS-T). Convalescent-phase rat serum was obtained from a female LEW rat, $17 \mathrm{~d}$ after intravenous injection with approximately $10^{8}$ c.f.u. of $M$. arthritidis ISR1p7. Control rat serum was obtained from uninfected LEW rats. For use in Western immunoblotting, rat sera were diluted 1:500 in PBS-T.

Colony immunoblotting. Colony immunoblots for detection of surface antigenic variants were prepared as previously described (Rosengarten \& Wise, 1990, 1991; Rosengarten et al., 1994). Briefly, nitrocellulose membrane discs (47 mm diameter; $0.45 \mu \mathrm{m}$ pore size; Schleicher \& Schuell) were placed on freshly grown mycoplasma colonies on the surface of agar plates. After $5 \mathrm{~min}$, the nitrocellulose discs were gently removed from the agar surface using blunt-ended forceps and placed with the colony side up in Petri dishes (50 mm diameter) containing the primary antibody (pAb anti-ISR1, anti-158p10, anti-PG6, anti$\mathrm{H} 606$ or anti-P36). After incubation overnight at $4{ }^{\circ} \mathrm{C}$, the unbound $\mathrm{pAb}$ was removed by three washes $(5 \mathrm{~min}$ each) with PBS. The blots were then incubated for at least $2 \mathrm{~h}$ at room temperature with horseradish-peroxidase-conjugated goat antiserum to rabbit immunoglobulins (Nordic), diluted $1: 1000$ in PBS. After three washes in PBS (5 min each), the colony blots were developed for 5-20 min with substrate solution containing 4-chloro-1-naphthol and hydrogen peroxide as described previously (Rosengarten et al., 1994).

Mycoplasma protein analysis. The procedures used for detergent phase fractionation with Triton X-114 (TX-114), SDSPAGE and Western immunoblotting of mycoplasma proteins have been recently described in detail (Rosengarten et al., 1994; Behrens et al., 1994). For SDS-PAGE (Laemmli, 1970), wholecell or phase-fractionated protein samples were treated at $100{ }^{\circ} \mathrm{C}$ for $5 \mathrm{~min}$ under reducing conditions and loaded onto $0.75 \mathrm{~mm}$ SDS $(9 \%, \mathrm{w} / \mathrm{v})$ polyacrylamide gels containing $3 \%(\mathrm{w} / \mathrm{v})$ urea (Rosengarten et al., 1994). Separated proteins were stained with Coomassie blue or silver (Blum et al., 1987) or were electrophoretically transferred to nitrocellulose membrane sheets (Towbin et al., 1979) and immunostained with the individual rabbit $\mathrm{pAbs}$ and rat sera as described before (Rosengarten $e$ al., 1994). Coomassie staining of gels was performed in three steps for $1 \mathrm{~h}$ each, using an aqueous solution containing $10 \%(\mathrm{v} / \mathrm{v}) 2$ propanol, $10 \%(\mathrm{v} / \mathrm{v})$ acetic acid and decreasing concentrations $(0.045 \%$, followed by $0.002 \%$ and $0.0009 \%)$ of Coomassie brilliant blue (G250, Serva). Gels were then destained overnight 
in $10 \%(\mathrm{v} / \mathrm{v})$ acetic acid. For Western immunoblot analysis with control (uninfected) and convalescent-phase sera, a peroxidase-conjugated rabbit antiserum against rat immunoglobulins (Nordic), diluted $1: 1000$ in PBS-T, was used as secondary antibody. Molecular masses were determined with prestained protein standards (low-range; Bio-Rad). Radiolabelled proteins were detected by fluorography as described elsewhere (Wise \& Kim, 1987; Bricker et al., 1988). To obtain strong autoradiographic signals, dried gels were exposed to films (X-Omat-AR; Kodak) for $3-14$ weeks $\left({ }^{35} \mathrm{~S}\right)$ or up to 43 weeks $\left({ }^{3} \mathrm{H}\right)$.

Treatment of intact mycoplasmas with trypsin and carboxypeptidase. Intact organisms from $48 \mathrm{~h}$ (early-exponential phase) broth cultures of selected $M$. arthritidis strains, substrains and subclones were treated with graded amounts $(0 \cdot 01,1$ and $10 \mu \mathrm{g}$ $\mathrm{ml}^{-1}$ ) of TPCK (L-1-tosylamide-2-phenylethyl-chloromethyl ketone)-trypsin (Sigma) or with graded amounts (0.078 and $0.78 \mathrm{mg} \mathrm{ml}^{-1}$ ) of carboxypeptidase $\mathrm{Y}$ (Pierce) as previously described (Rosengarten et al., 1994; Behrens et al., 1994). Samples were incubated for $1 \mathrm{~h}$ (trypsin) or $20 \mathrm{~h}$ (carboxypeptidase) at $37^{\circ} \mathrm{C}$, processed for SDS-PAGE, and the digestion products analysed in Western immunoblots with $\mathrm{pAbs}$ as described above.

\section{RESULTS}

\section{Polyclonal antibodies to $M$. arthritidis strains and substrains identify a prominent set of strain-variant antigens}

In order to define specific $M$. arthritidis antigens and to monitor their distribution among strains, equivalent amounts of stock cultures of $M$. artbritidis ISR1p7, 158p10, PG6, H606 and D263 were analysed in Western immunoblots using a panel of four pAbs to whole $M$. artbritidis organisms (Fig. 1). All four antisera (anti-ISR1, panel a; anti-158p10, panel b; anti-PG6, panel c; antiH606, panel d) recognized a rather restricted number of antigenic components. Nine prominent antigens with molecular masses ranging between 36 and $120 \mathrm{kDa}$ were identified that showed marked differences in the apparent levels of expression among the five broth-cultured populations analysed. Interestingly, while the immunoblot profiles of substrains ISR1p7 (lanes 1) and 158p10 (lanes 2) and strains PG6 (lanes 3) and H606 (lanes 4) were clearly distinct from one another, the antigen profile of strain D263 (lanes 5) was virtually identical with that of substrain ISR 1p7, indicating a close antigenic relationship between these two isolates. The $\mathrm{pAb}$ immunoblot patterns shown in Fig. 1 were highly reproducible and essentially unchanged when organisms from different passages or from different growth phases were analysed (data not shown). In parallel experiments using greatly increased amounts of proteins, some of the prominent strain-variant antigens identified by the pAbs were shown to stain strongly with Coomassie blue (62 and $43 \mathrm{kDa}$ bands) and/or with silver (120 and $62 \mathrm{kDa}$ bands) (data not shown).

\section{Altered expression of $M$. arthritidis antigens following in vivo passage of strains}

To investigate whether antigenic variation occurs during infection, we compared the Western immunoblot profiles (Fig. 2) of strains ISR1 (panels a-c, lanes 1) and D263 (panels $d-f$, lanes 1 ) with their rat-passaged substrains ISR1p1 (panels a-c, lanes 2), ISR1p7 (panels a-c, lanes 3), ISR1p8 (not shown) and D263p1 (panels $\mathrm{d}-\mathrm{f}$, lanes 2), respectively. Using the same set of pAbs as in Fig. 1, we were able to demonstrate significant differences among the parental strains and their rat-passaged substrains in the distribution and relative amounts of specific antigens. Notably, a prominent antigen of $32 \mathrm{kDa}$ was identified by anti-PG6 (panels $b$ and e) and anti-H606 (panels $c$ and $f$ ) in substrains ISR1p1 (panels a-c, lanes 2), ISR1p8 (not shown) and D263p1 (panels $d-f$, lanes 2) that was absent in the parental strains ISR1 (panels a-c, lanes 1) and D263 (panels $\mathrm{d}-\mathrm{f}$, lanes 1 ).
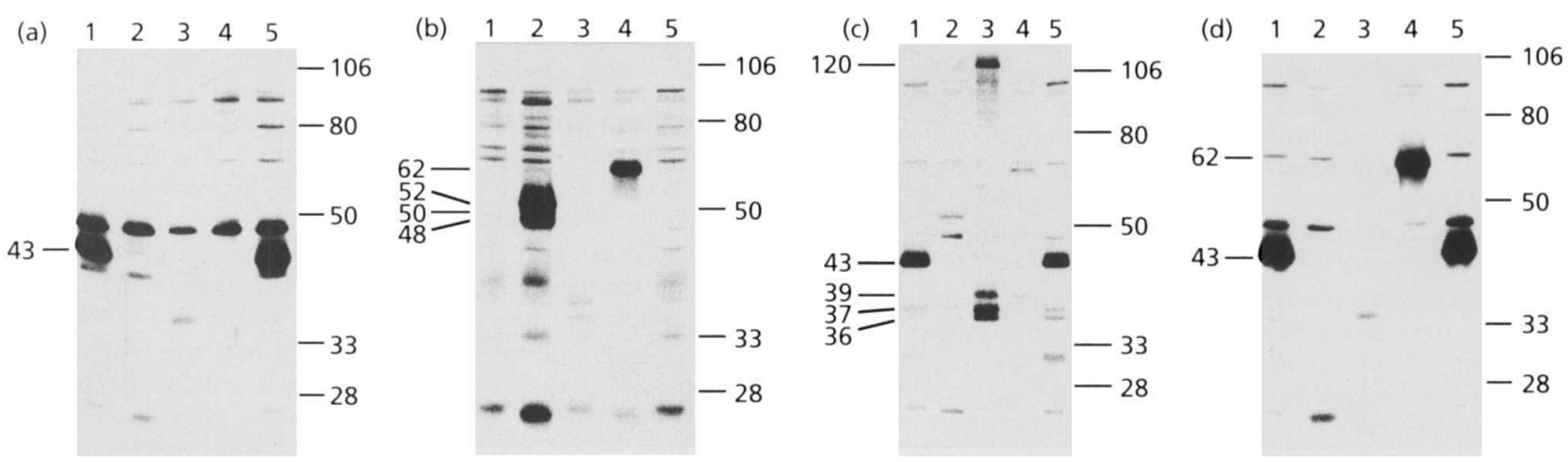

\footnotetext{
Fig. 1. Antigenic profiles of three representative $M$. arthritidis strains and two rat-passaged substrains. Proteins from broth-cultured whole organisms of substrains ISR1p7 (lanes 1) and 158p10 (lanes 2), and strains PG6 (lanes 3), H606 (lanes 4) and D263 (lanes 5) were separated by SDS-PAGE and immunoblotted with pAb anti-ISR1 (a), anti-158p10 (b), anti-PG6 (c) or anti-H606 (d). Each lane contained proteins from $110 \mu \mathrm{l}$ of exponential-phase cultures. The positions and molecular masses (in $\mathrm{kDa}$ ) of major strain-variant antigens are indicated on the left of each panel. The positions of molecular mass markers (in $\mathrm{kDa}$ ) are indicated on the right of each panel.
} 

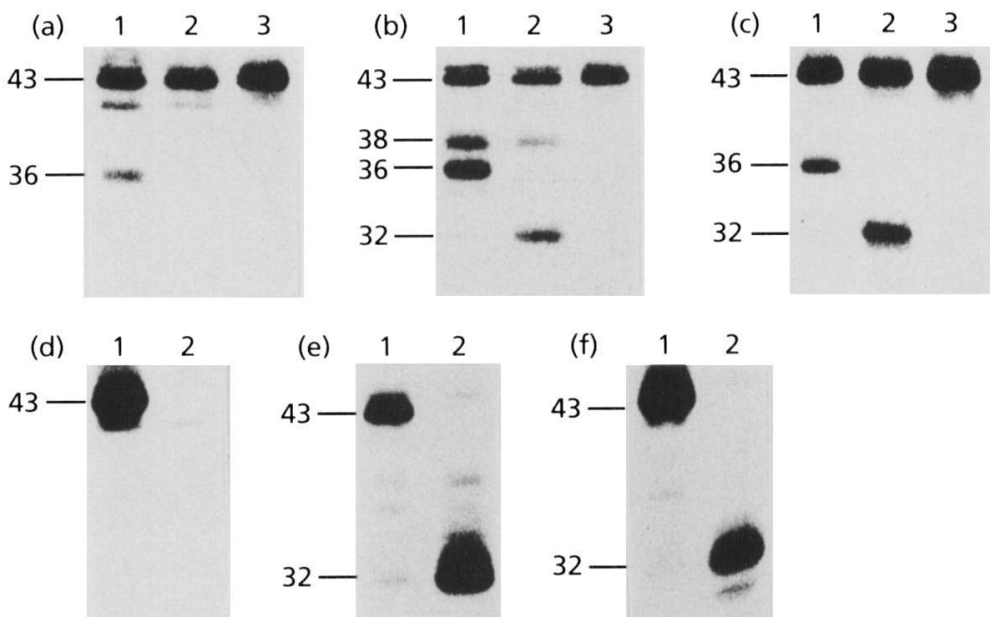

Fig. 2. Changes in antigen profile of $M$. arthritidis strains ISR1 and D263 after animal passages. Whole cell proteins from $110 \mu \mathrm{l}$ of nid-exponential phase broth cultures were subjected to SDS-PAGE and immunoblotted ivith pAb anti-ISR1 ( $a$ and d), anti-PG6 (b and $e$ ) or anti-H606 ( $c$ and $f$ ). The lanes show: (a-c) strain ISR1 (lanes 1) and ratpassaged substrains ISR1p1 (lanes 2) and ISR1p7 (lanes 3); (d-f) strain D263 (lanes 1) and substrain D263p1 (lanes 2). Antigens showing variable expression among original strains and animal-passaged substrains are indicated, as well as a $43 \mathrm{kDa}$ antigen that shows stable expression in all three ISR1 populations.
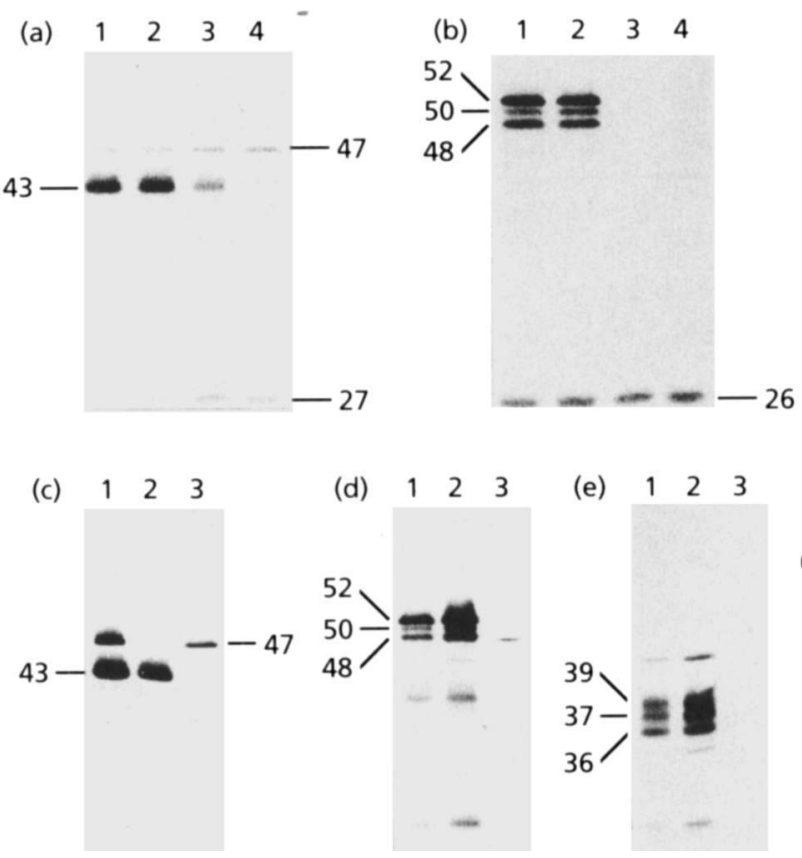

Fig. 3. Trypsin sensitivity and detergent phase partitioning characteristics of selected $M$. arthritidis strain-variant antigens. $(\mathrm{a}, \mathrm{b})$ Fresh broth-grown cells $(90 \mu \mathrm{l}$ of culture per sample) of ISR1p7 (a) and 158p10 (b) incubated with trypsin were subjected to SDS-PAGE and the subsequent Western blots immunostained with PAb anti-ISR1 (a) or anti-158p10 (b). Lanes 1 represent organisms incubated in enzyme buffer; lanes 2, 3 and 4 represent organisms treated with, respectively, $0.01,1$ or $10 \mu \mathrm{g}$ trypsin $\mathrm{ml}^{-1}$. Positions and molecular masses (in $\mathrm{kDa}$ ) of trypsin-sensitive strain-variant antigens are indicated on the left and other antigens recognized on the right. (c-f) Broth-cultured organisms of ISR1p7 (c), 158p10 (d), PG6 (e) and $\mathrm{H} 606$ (f) were phase-fractionated. The panels show proteins from whole organisms (lanes 1), TX-114 (lanes 2) or aqueous (lanes 3) phases separated by SDS-PAGE and immunoblotted with PAb anti-ISR1 (c), anti158 p10 (d), anti-PG6 (e) or anti-H606 (f). Positions and molecular masses (in $\mathrm{kDa}$ ) of strain-variant antigens identified by pAbs to selectively partition into the detergent phase are indicated on the left. The $120 \mathrm{kDa}$ antigen of strain PG6 (see Fig. 1c, lane 3), not shown in (e), also partitioned into the TX-114 phase. Samples contained whole-cell or phase-fractionated proteins derived from approximately 60 (lanes 1), 1100 (lanes 2) or 110 (lanes 3) $\mu \mathrm{l}$ of mid-exponential phase cultures.

\section{M. arthritidis variant antigens are surface-exposed integral membrane proteins and lipoproteins}

In order to define the location and biochemical nature of the pAb-defined strain-variant antigens of $M$. artbritidis, intact organisms of all nine strains and substrains were harvested from fresh broth cultures and treated with increasing concentrations of trypsin. The complete reaction mixtures were then subjected to SDS-PAGE and subsequent blots immunostained with the individual pAbs. All variant antigens showed graded abrogation of antibody binding, while the immunostaining intensity of some invariant antigens was unaffected by trypsin treatment. Four examples of this selective trypsin sensitivity of $M$. arthritidis antigens are shown in Fig. 3 for substrains ISR1p7 (panel a) and 158p10 (panel b): in contrast to the three invariant antigens of 47,27 (panel a) and 26 (panel b) $\mathrm{kDa}$ which were resistant to trypsin digestion of whole 
Table 2. Properties of $M$. arthritidis variable membrane proteins

\begin{tabular}{|c|c|c|c|c|}
\hline $\begin{array}{l}\text { Variable } \\
\text { membrane } \\
\text { protein* }\end{array}$ & $\begin{array}{c}\text { Amphiphilic } \\
\text { property } \dagger\end{array}$ & $\begin{array}{c}\text { Lipid } \\
\text { modification } \ddagger\end{array}$ & $\begin{array}{c}\text { Defining } \\
\text { pAbs } ₫\end{array}$ & $\begin{array}{l}\text { M. arthritidis } \\
\text { strains/ } \\
\text { substrains } \|\end{array}$ \\
\hline P120 & + & NT & $\mathrm{C}$ & PG6 \\
\hline P80 & + & - & $\mathrm{B},(\mathrm{C})$ & $158 \mathrm{p} 10$ \\
\hline P62 & + & NT & $\mathrm{B}, \mathrm{D}$ & $\mathrm{H} 606$ \\
\hline P52 & + & - & $\mathrm{B},(\mathrm{C})$ & $158 \mathrm{p} 10$ \\
\hline P50 & + & - & B & $158 \mathrm{p} 10$ \\
\hline P48 & + & - & $\mathrm{B},(\mathrm{C})$ & $158 \mathrm{p} 10$ \\
\hline P43 & + & - & $A, C, D, E$ & $\begin{array}{l}\text { ISR1, ISR1p1, } \\
\text { ISR1p7, ISR1p8, } \\
\text { 158p10, D263 }\end{array}$ \\
\hline P40 & + & - & $\mathrm{A}, \mathrm{C}, \mathrm{D}$ & $\mathrm{H} 606$ \\
\hline P39 & + & - & $C, D$ & PG6, H606 \\
\hline P38 & + & - & $\mathrm{C}$ & ISR 1, ISR $1 \mathrm{p} 1$ \\
\hline P38' & + & + & $\mathrm{A}, \mathrm{C}$ & ISR $1 \mathrm{p} 7$ \\
\hline P38" & + & + & (A), (D) & $158 \mathrm{p} 10$ \\
\hline P37 & + & + & $\mathrm{A}, \mathrm{C},(\mathrm{D})$ & $\mathrm{H} 606$ \\
\hline P37' & + & + & $\mathrm{A}, \mathrm{C},(\mathrm{D}),(\mathrm{E})$ & PG6 \\
\hline P37" & + & - & $\mathrm{B}, \mathrm{C}$ & $158 \mathrm{p} 10$ \\
\hline P36 & + & + & $\mathrm{A}, \mathrm{B}, \mathrm{C}, \mathrm{D}, \mathrm{E}$ & $\begin{array}{l}\text { ISR1, ISR1p7, } \\
\text { 158p10, H606 }\end{array}$ \\
\hline P36 & + & - & $A, C, D, E$ & PG6 \\
\hline P32 & + & + & $C, D$ & $\begin{array}{l}\text { ISR1p1, } \\
\text { ISR1p7, } \\
\text { ISR1p8, D263p1 }\end{array}$ \\
\hline P32' & + & + & B, C, D & $158 \mathrm{p} 10$ \\
\hline
\end{tabular}

* Designated by apparent molecular mass in $\mathrm{kDa}$ as determined by Western immunoblot analysis with pAbs.

† Determined by selective partitioning into the detergent phase during TX-114 phase fractionation.

$\ddagger$ Determined by metabolic labelling of TX-114-phase proteins with $\left[{ }^{3} \mathrm{H}\right]$ palmitate. NT, Not tested;,- not detectable.

\A, anti-ISR1; B, anti-158p10; C, anti-PG6; D, anti-H606; E, anti-P36 (see Methods). Parentheses indicate weak reaction.

|| Including clonal subpopulations of strains PG6 and H606 and substrains ISR1p7 and 158p10.

cells, the variant antigens of 43 (panel a), 52, 50 and 48 (panel b) $\mathrm{kDa}$ were progressively degraded to completion. This clearly indicated that the variant antigens of $M$. arthritidis were surface-located proteins.

To assess the association of these surface-exposed proteins with the mycoplasma membrane, broth-grown cells of $M$. artbritidis strains and substrains were subjected to TX-114 detergent phase fractionation, and the fractions analysed by SDS-PAGE and Western immunoblotting. As demonstrated in Fig. 3 for substrains ISR1p7 (panel c) and 158p10 (panel d), and strains PG6 (panel e) and H606 (panel $f$ ), all variant antigens (lanes 1 ) recognized by the pAbs clearly separated as amphiphilic (TX-114 phase) proteins (lanes 2), while the invariant $47 \mathrm{kDa}$ antigen of substrain ISR1p7 (panel c) partitioned as a hydrophilic (aqueous phase) protein (lane 3). The majority of proteins detected in Coomassie-blue- and silver-stained gels were also hydrophilic (data not shown). Thus, based on their preferential interaction with detergent micelles, the strainvariant surface antigens of $M$. artbritidis could be provisionally classified as integral membrane proteins. To test whether they were lipid-modified, fluorographs of SDS-PAGE-separated TX-114-phase proteins of organisms metabolically labelled with $\left[{ }^{35} \mathrm{~S}\right]$ cysteine or $\left[{ }^{3} \mathrm{H}\right]$ palmitate were compared with corresponding pAbimmunoblots. This analysis identified two distinct sets of variant surface antigens corresponding to two classes of integral membrane proteins (Table 2), namely (i) lipoproteins which labelled strongly with both compounds, and (ii) proteins which failed to demonstrate any incorporation of fatty acid, although cysteine was present in some of these products. Three examples are shown in Fig. 4. While the $32 \mathrm{kDa}$ antigen (designated $\mathrm{P} 32$, lanes 1 ; see also Fig. $2 \mathrm{~b}$ and c, lanes 2, and Fig. 2e and f, lanes 2) and the $36 \mathrm{kDa}$ antigen (designated P36, lanes 3; see also Fig. 

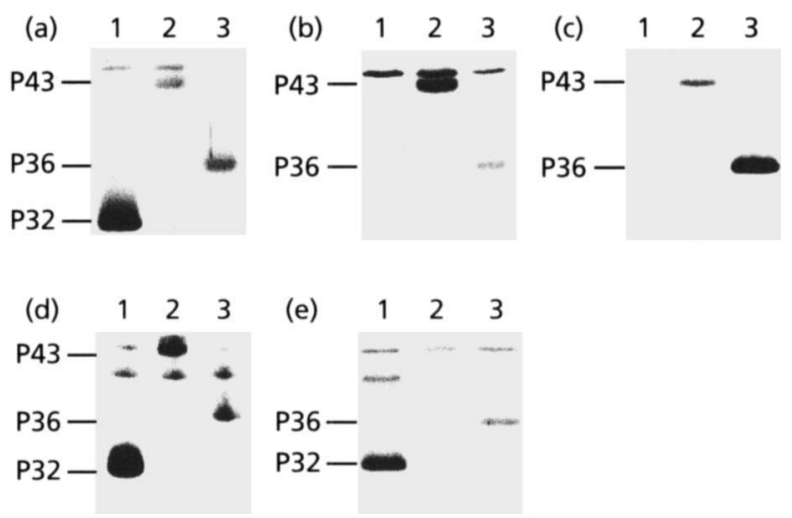

Fig. 4. Antigenic profiles and labelling characteristics of selected $M$. arthritidis membrane proteins showing variation in expression among clonal isolates. Whole-cell proteins $(a-c)$ or TX-114-phase proteins labelled with $\left[{ }^{35} \mathrm{~S}\right]$ cysteine (d) or [ ${ }^{3} \mathrm{H}$ ]palmitate (e) from selected clonal isolates (lanes 1-3) of substrain ISR1p7 were separated by SDS-PAGE and immunoblotted with pAb anti-PG6 (a), anti-ISR1 (b) or anti-P36 (c), or analysed by fluorography ( $d$ and e). Samples contained proteins from $110(a-c)$ or 1700 (d and e) $\mu$ l of mid-exponentialphase cultures. Variable membrane proteins visualized by immunostaining and/or labelling are indicated on the left of each panel and are designated by their molecular mass in $\mathrm{kDa}$.

2a-c, lanes 1, and Fig. 5d-g, lanes 3) were cysteinelabelled (panel d) and palmitate-labelled (panel e) lipoproteins, the $43 \mathrm{kDa}$ antigen (designated $\mathrm{P} 43$, lanes 2 ; see also Fig. 1a-c, lanes 1 and 5, Fig. 2a-c, lanes 1, 2 and 3, and Fig. $2 d-f$, lanes 1 ) contained cysteine (panel d), but did not label with palmitate (panel e).

To further assess how these variant membrane proteins and lipoproteins were oriented on the mycoplasma cell surface, whole cells of $M$. artbritidis strain ISR1 expressing the lipoprotein P36 and the protein P43 (Fig. 2a-c, lanes 1) were treated with graded concentrations of carboxypeptidase Y. Western immunoblots of these digestion reaction mixtures showed generation of $1 \mathrm{kDa}$ smaller truncation products in partially digested preparations and graded abrogation of staining of the shortened proteins in more extensively digested preparations (data not shown). Thus, the two variant proteins P36 and P43 were clearly susceptible to external digestion with carboxypeptidase, indicating that their $\mathrm{C}$-termini were accessible on the mycoplasma surface.

\section{The repertoire of $\boldsymbol{M}$. arthritidis variant membrane proteins and lipoproteins includes strain-specific and common antigens which display epitopic differences and similarities}

The repertoire of variant surface membrane protein antigens of particular $M$. arthritidis strains appeared underrepresented in broth-passaged stock cultures compared to in vivo passaged substrains (see above). This finding prompted us to examine individual colonies of strains and/or substrains, a strategy recently suggested by
Theiss et al. (1993). By comparing the pAb reaction profiles and labelling patterns of TX-114-phase proteins of numerous clonally derived subpopulations of $M$. artbritidis ISR1p7 (see Fig. 4a, b, d and e, and Fig. 5a), 158p10 (see Fig. 5d, e and f), PG6 (data not shown) and H606 (data not shown), we were able to identify an expanded repertoire of 18 distinct antigenic products (Table 2), some of which were clearly associated with lipid (e.g. P32 and P36, see Fig. 4e, lanes 1 and 3).

Serological cross-reactivity may exist among several variant membrane proteins of $M$. artbritidis (see Table 2). In an attempt to more precisely define the antigenic relatedness among some of these proteins by identifying common epitopes, pAb anti-P36 was used as a probe in Western blots of whole organisms (strains, substrains and clonal variants) expressing the entire set of variant membrane proteins. The $\mathrm{pAb}$ was not monospecific; it bound not only the corresponding immunizing protein (P36), but also three other variant proteins, namely P43 (Fig. 4c and 5g, lanes 2), P37' (data not shown) and P36' (data not shown). This result demonstrated that $\mathrm{pAb}$ antiP36 had epitope specificities distinct from those of antiISR1, anti-158p10, anti-PG6 and anti-H606, and identified the $37 \mathrm{kDa}$ protein of strain PG6 as a new variant protein (designated $\mathrm{P} 37^{\prime}$ ) distinct from the $\mathrm{P} 37$ of strain $\mathrm{H} 606$ (see Table 2).

However, the majority of variant membrane protein antigens listed in Table 2 appeared to be restricted to one particular M. artbritidis strain. Only four proteins (P32, P36, P39 and P43) were identified in more than one $M$. artbritidis strain. Thus, the repertoire of variant surface antigens of each $M$. artbritidis strain includes both strainspecific and common antigens.

\section{High-frequency in vitro phase variation of $\boldsymbol{M}$. arthritidis membrane proteins and lipoproteins}

Having established a set of multiple antigenic surfaceexposed membrane proteins which differ in expression among strains, substrains, and clonal isolates of $M$. artbritidis, we examined the ability of this organism to undergo high-frequency antigenic variation, using previously established methods (Rosengarten \& Wise, 1990 , 1991; Theiss et al., 1993; Behrens et al., 1994; Yogev et al., 1994). A series of clonal lineages initiated from clonal isolates of $M$. artbritidis ISR1p7, 158p10, PG6 and H606 stock cultures and selected by their pAb-immunoblot profiles for altered expression of specific membrane proteins provided clear indication of on/off switching involving all variant proteins defined in this study (Table 2). Fig. 5 shows three examples of such switches in clonal lineages of substrains ISR1p7 (panel a) and 158p10 (panels $\mathrm{d}-\mathrm{g}$ ), defined by Western immunoblots of whole organisms stained with pAb anti-ISR1 (panels a and $\mathrm{f}$ ), anti-158p10 (panel d), anti-PG6 (panel e) or anti-P36 (panel $\mathrm{g}$ ). All four $\mathrm{pAbs}$ demonstrate phase variation in expression of at least two membrane protein antigens, including P43, P38' and P36 in panel a, and P43, P38", P37", P36 and P32' in panels d-g. Notably, all of these 


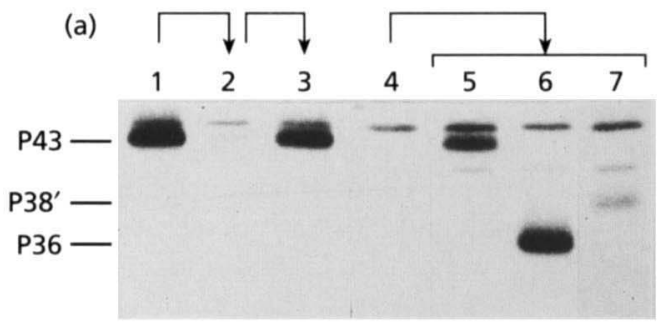

(b)

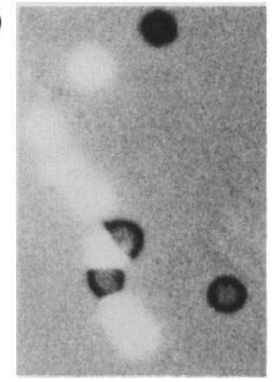

(c)

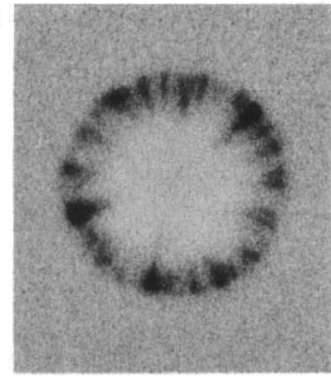

(d)
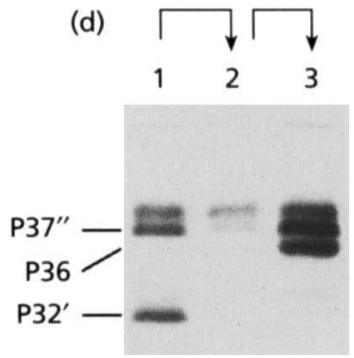

(e)

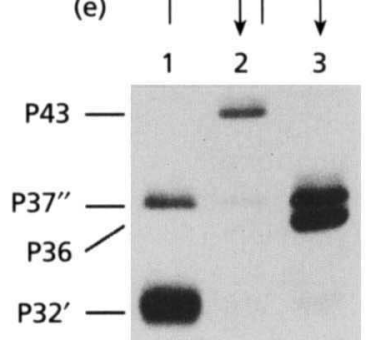

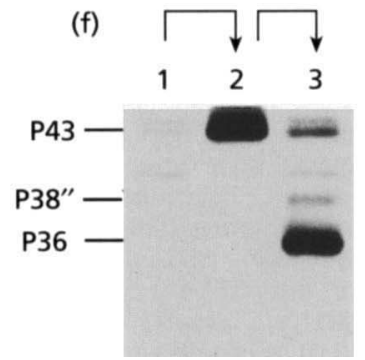

(g)
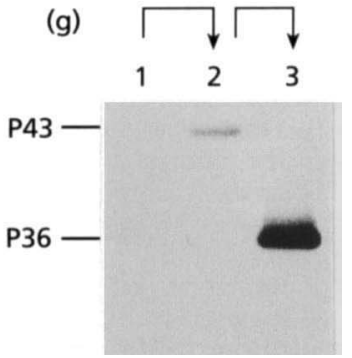

Fig. 5. High-frequency phase variation in expression of selected membrane proteins in $M$. arthritidis clonal lineages demonstrated by Western and colony immunoblot analysis. $(a, d-g)$ Whole-cell proteins from two clonal lineages of substrain ISR1p7 (a) and one clonal lineage of substrain 158p10 (d-g) were separated by SDS-PAGE and immunoblotted with pAb anti-ISR1 (a, f), anti-158p10 (d), anti-PG6 (e) or anti-P36 (g). Each lane contained proteins from $110 \mu$ of midexponential-phase cultures. Membrane proteins identified by pAbs to oscillate between 'phase on' and 'phase off' expression states are indicated on the left of each panel. Phase transitions between sequential clones are indicated by arrows above lanes; sibling clones (a) are indicated by brackets. (b, c) Colony blots of $M$. arthritidis PG6 immunostained with pAb anti-P36 showing (b) phenotypically positive (reactive), negative (nonreactive) or (c) mixed (sectored) colonies.

proteins appeared to be expressed independently of one another, since no two displayed the same expression states throughout several switches analysed (Fig. 5a and d-g).

A second tool that provided clear evidence of surface antigen switching in clonal populations of $M$. arthritidis strains and substrains was the colony immunoblot technique. When pAb anti-P36 was used as immunological probe, colonies derived from a single cloned isolate of $M$. arthritidis ISR1p7, 158p10, PG6 or H606 often displayed a marked heterogeneity in immunostaining intensity, that enabled us to define positive (stained), negative (unstained) and mixed (sectored) pAb-binding phenotypes. These are illustrated in Fig. 5(b, c), showing imprints of colonies of clonal subpopulations of the PG6 strain immunostained with $\mathrm{pAb}$ anti-P36. In contrast, pAbs anti-ISR1p7, anti-158p10, anti-PG6 and anti-H606 failed to detect any differences in the level of reactivity among colonies (data not shown). Further propagation and plating of individual positive and negative variants detected by $\mathrm{pAb}$ anti-P36 gave rise to variants displaying the alternate (negative or positive) phenotype at a high frequency, with average switch frequencies ranging from $1.2 \times 10^{-4}$ to $1.8 \times 10^{-2}$ per generation, depending on the protein monitored and the population examined. Western immunoblot analysis of selected progenitor and progeny colonies also clearly demonstrated that expression of the proteins recognized by this $\mathrm{pAb}$ (i.e. P43, P37', P36 and
P36') was subject to high-frequency phase variation (data not shown).

\section{$M$. arthritidis variable membrane proteins are immunogenic during infection and disease}

To initially assess whether the variable membrane proteins of $M$. arthritidis may play a role in interactions with the host during infection, and therefore are recognized by rat antibodies, serum from a rat taken after experimental infection with $M$. artbritidis substrain ISR1p7, as well as control serum from an uninfected rat, were used to probe Western blots of broth-cultured whole organisms of $M$. artbritidis strains, substrains and clonal isolates (Fig. 6). In contrast to the control rat serum, which showed no reaction (data not shown), the convalescent-phase serum showed strong and specific staining of the phase-variable membrane surface proteins P43, P39, P37, P36, P32 and P32'. Western immunoblot analysis of convalescent-phase sera of $M$. artbritidis ISR1p7-infected rats from other experiments confirmed these data. All animals developed strong and preferential antibody reactions to these proteins (data not shown). These results demonstrated that the $\mathrm{pAb}$-defined variable membrane surface proteins of $M$. arthritidis were major immunogens of this organism. It could not, however, be directly established whether they alternated in expression during infection and disease 


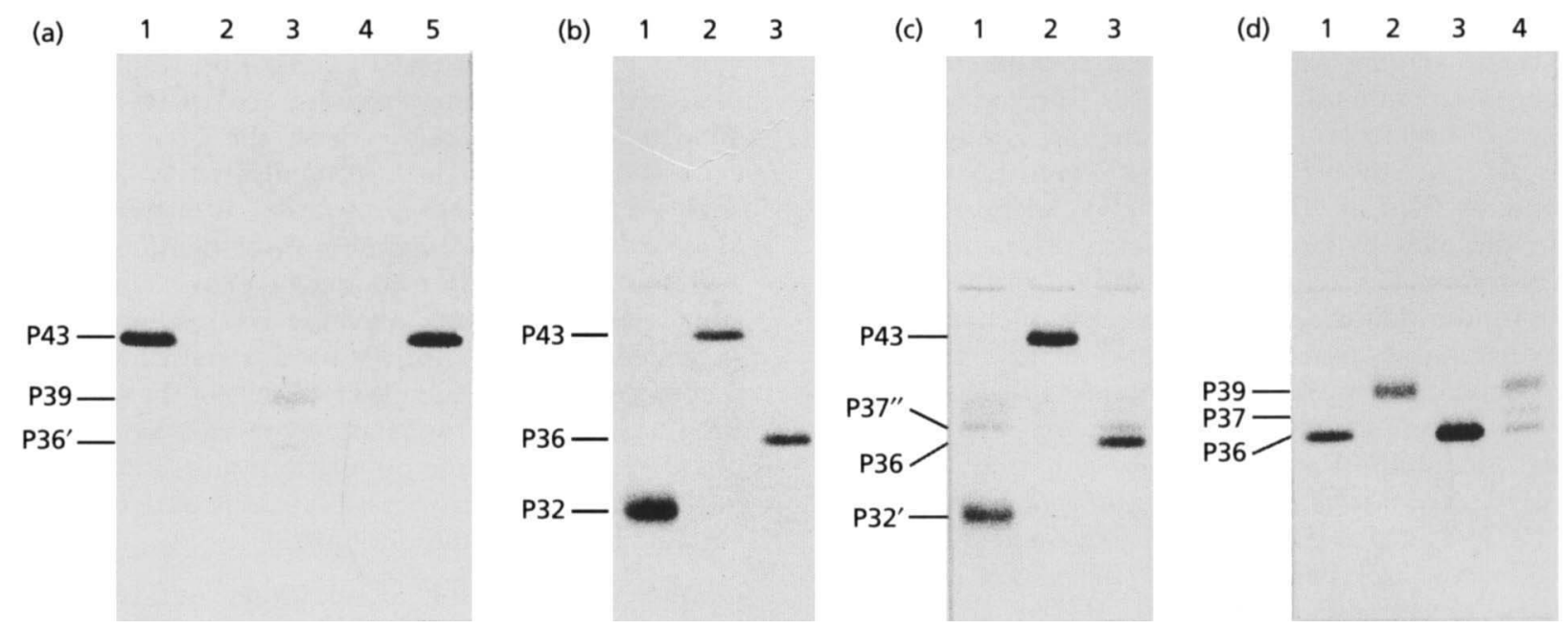

\begin{abstract}
Fig. 6. Selective recognition of $M$. arthritidis strain- and phase-variant membrane proteins by serum antibodies from a convalescent rat. Whole-cell proteins from $110 \mu \mathrm{l}$ of mid-exponential-phase cultures of $M$. arthritidis strains, substrains and clonal variants were subjected to SDS-PAGE, and subsequent Western blots immunostained with convalescent-phase serum from a rat after experimental infection with $M$. arthritidis ISR1p7. The lanes show: (a) substrains ISR1p7 (lane 1) and 158p10 (lane 2), and strains PG6 (lane 3), H606 (lane 4) and D263 (lane 5); (b) clonal isolates of substrains ISR1p7, corresponding to those in Fig. 4; (c) subclones of substrain 158p10, corresponding to those in Fig. $5(d-g)$; (d) selected clonal isolates of strain $\mathrm{H606}$. Variable membrane proteins showing strong or weak reaction with rat serum antibodies are indicated on the left of each panel.
\end{abstract}

and/or whether they were recognized by some rat antibodies directed toward common epitopes.

\section{DISCUSSION}

Highly evolved systems of surface antigenic variation exist in several pathogenic mycoplasmas (Wise et al., 1992; Wise, 1993), endowing them with remarkable phenotypic and genetic flexibility. However, while the products, parameters and genes underlying this variation have been well-defined in some species, for instance, the Vlp system of M. byorbinis (Rosengarten \& Wise, 1990, 1991; Yogev et al., 1991), the pMGA system and PvpA of M. gallisepticum (Markham et al., 1992, 1993, 1994; Yogev et al., 1994), and the Vsp system of M. bovis (Rosengarten et al., 1994; Behrens et al., 1994), the potential biological functions have not. Although it is widely assumed that these variable surface antigens contribute to the organism's survival and persistence in the infected host, this is as yet unproven. However, an important role is indicated by (i) their prevalence as major immunogens recognized by serum antibodies from infected hosts (Rosengarten \& Wise, 1991; Markham et al., 1992; Rosengarten et al., 1994; Yogev et al., 1994), and (ii) their possible involvement in adhesion to host cells, as suggested by demonstration of adherence properties (Krause \& Taylor-Robinson, 1992; Markham et al., 1992; Watson et al., 1993; Simmons et al., 1994) or by analogy with the well-established function of molecular homologues (D. Yogev, D. Menaker \& R. Rosengarten, unpublished results).

The increasing need to understand the possible role of variable surface antigens in immune evasion and/or pathogenesis prompted us to examine the existence and nature of such antigens in $M$. arthritidis with the intention to use the well-established rat model of $M$. artbritidisinduced polyarthritis as tool to investigate mycoplasma antigenic variation in vivo and to assess its potential significance during infection and disease. Recently, evidence of antigenic differences among strains of $M$. artbritidis (Washburn \& Hirsch, 1990; Stadtländer \& Watson, 1992; Washburn et al., 1995) has been reported. However, these studies provide virtually no information defining the biochemical nature and cellular location of these antigens or the mechanims underlying the reported strain differences, i.e. whether the phenotypes observed represent stable subpopulations due to environmental selection or merely distinct antigenic variants evolved from phase and antigenic variation. Using a set of $\mathrm{pAb}$ reagents developed here and in previous studies (Kirchhoff et al., 1983a; Washburn et al., 1985, 1988; Washburn \& Hirsch, 1990), as well as previously established strategies (Rosengarten \& Wise, 1990, 1991; Rosengarten et al., 1994; Behrens et al., 1994), we have identified in this report numerous prominent and discrete membrane proteins and lipoproteins which (i) are exposed on the surface of $M$. artbritidis, (ii) include apparent strainspecific and common antigens, (iii) are subject to highfrequency in vitro phase variation, (iv) are dominant targets of the host immune response, and (v) undergo changes in apparent levels of expression during in vivo passage.

Several features which delineate the $M$. arthritidis system of surface antigenic variation as an important model were revealed in this study. A key feature of the $M$. artbritidis system is its structural complexity, which underscores 
(Fig. 4, Table 2) the recent observation (Yogev et al., 1994) that mycoplasmas may employ two different types of integral membrane proteins for surface variation, namely (i) lipoproteins, which are, according to the widely accepted model of prokaryotic and mycoplasmal lipoproteins (Wu, 1987; Wise, 1993), anchored in the membrane solely by fatty acid moieties covalently bound to an $\mathrm{N}$-terminal cysteine residue, and (ii) proteins which are not lipid-modified and are membrane-anchored solely via hydrophobic transmembrane domains. However, while variable membrane lipoproteins and their genes have now been characterized in several mycoplasma species, including $M$. byorbinis (Rosengarten \& Wise, 1990, 1991; Yogev et al., 1991), M. gallisepticum (Markham et al., 1993; Yogev et al., 1994), M. fermentans (Wise et al., 1993; Theiss et al., 1993), M. bovis (Behrens at al., 1994), M. pulmonis (Simmons et al., 1994), M. bominis (Olson et al., 1991a; Christiansen et al., 1994) and U. urealyticum (Teng et al., 1994), variable proteins which are not lipidmodified have not. The only known examples of mycoplasma phase-variant membrane surface proteins that are not lipid-modified are the P30 adhesin of $M$. pneumoniae (Dallo et al., 1990) and the recently described adhesin-like protein PvpA of M. gallisepticum (Yogev et al., 1994; D. Yogev, D. Menaker \& R. Rosengarten, unpublished results). Thus, our discovery of phase-variant protein antigens in $M$. artbritidis which are not lipid-modified extends the reported cases of surface antigenic variation systems in mycoplasmas involving this type of membrane surface protein. Moreover, from the perspective that variable proteins and lipoproteins may serve different functions in the organism's survival and pathogenicity, such as providing escape from immune surveillance, mediating specific interactions with the host, or modulating a variety of immune responses, the finding that $M$. arthritidis can express a repertoire of both types of proteins independently of each other underscores the advantage of this organism as a model for future studies addressing some of these issues.

A second important feature of the variable membrane proteins of $M$. arthritidis which has, however, not been fully established in this report is their apparent strain specificity (Fig. 1, Table 2). It has previously been pointed out that reported antigenic differences among strains of $M$. byorbinis (Rosengarten \& Wise, 1990, 1991), $M$. fermentans (Theiss et al., 1993) and M. bovis (Rosengarten et al., 1994) reflect distinct patterns of phase-variant antigens. Our results confirm that at least some of the striking differences seen in the antigen expression profiles of $M$. artbritidis strains and/or substrains are equally due to high-frequency phase variation of specific membrane proteins. For instance, when stock cultures of $M$. artbritidis ISR1p7, 158p10, PG6, H606 and D263 were analysed by Western immunoblots with pAbs anti-ISR1, anti-158p10, anti-PG6 and anti-H606 (Fig. 1), P43 appeared to be 'specific' for substrain ISR1p7 and strain D263. However, when a large number of clonal isolates of substrain 158p10 and strains PG6 and H606 were immunoscreened with the same set of pAbs, a minor subpopulation of substrain 158p10 was found that expressed
P43. Since P43 was demonstrated to undergo rapid phase variation in expression (Fig. 5), this result clearly established that the apparent 'absence' of P43 in substrain $158 \mathrm{p} 10$ (Fig. 1) merely reflects the predominant $\mathrm{P}^{-} 3^{-}$ expression state of the broth-cultured bulk population analysed. Whether P43 is also present in strains PG6 and H606 could not be unambigously demonstrated here. Although all attempts to detect expression of P43 in clonal subpopulations of these strains have been unsuccessful, the presence of this antigen cannot be ruled out, since failure to identify P43 within these strains may simply be due (i) to the relatively rare occurrence of $\mathrm{P}^{+} 3^{+}$ phase variants in these populations and (ii) in particular, to the lack of a selective antibody able to detect such rare variants in colony immunoblots.

Despite these unresolved questions, our results extend our understanding of differential surface antigen expression in $M$. artbritidis strains. Firstly, it seems quite possible that the full repertoire of $M$. arthritidis variable membrane proteins and lipoproteins includes both strainspecific as well as common antigens which are either present in all strains or selectively associated with a restricted set of strains (Table 2). Secondly, to precisely define antigenic differences and similarities among $M$. arthritidis strains, careful examination of the populations at the level of colonies is needed, since broth-passaged stock cultures may underrepresent some strain-specific or common antigens, an important aspect which has been discussed previously for $M$. fermentans (Wise et al., 1993; Theiss et al., 1993). Thirdly, in light of the possibility that some variable membrane proteins are in fact strain-specific antigenic markers while others are common antigens restricted to a particular set of strains, it is very likely that antigenic drift due to accumulated mutational events plays a substantial role in $M$. artbritidis strain diversification and determines the degree of antigenic relationship among individual strain populations. Considering the origin of the strains examined in this study (Table 1), it is indeed somewhat surprising that strain ISR1 (including its substrains), isolated from rat, appears to be more closely related to strain D263, isolated from swine, than to any other of the three rat and mouse isolates (158p10, PG6 and H606) (Table 2). Nevertheless, since strain D263 and its rat-passaged derivative D263p1 have as yet only been examined as bulk populations (Fig. $2 \mathrm{~d}-\mathrm{f}$ ), it is not unlikely that detailed analysis by colony plating will reveal a repertoire of variable membrane proteins that is different from that of strain ISR1 and includes D263specific antigens.

Another key question which remains unresolved is the precise antigenic relationship among the several $M$. artbritidis membrane surface proteins described in this study. The distinction between proteins was based on their $\mathrm{pAb}$ reaction profiles, their apparent size and their $\left[{ }^{3} \mathrm{H}\right]$ palmitate labelling patterns (Table 2). However, using the combined $\mathrm{pAb}$ epitope profile as the only discriminating criterion, quite distinctive sets of antigenically related, but different-sized products could be identified (Table 2). In the first place, this is highly reminiscent of size-variant antigens which have been 
identified in other mycoplasma systems, such as in the Vlp system of M. hyorbinis (Boyer \& Wise, 1989; Rosengarten \& Wise, 1990, 1991), the Vsp system of $M$. bovis (Rosengarten et al., 1994; Behrens et al., 1994) and the Vsp counterpart of M. gallisepticum, PvpA (Yogev et al., 1994). To date, however, it is not yet fully established whether similar mechanisms to generate antigen size variation also operate in $M$. artbritidis. Nevertheless, although we can conclude from the biochemical and immunological data obtained in this and a more recent study (Tangen $e t$ al., 1994) that the antigenically closely related phase-variant membrane proteins of $M$. arthritidis do not represent different size versions of only a few products, the possibility that these and other phase-variant membrane proteins of this species undergo size variation cannot be ruled out.

The identification of these variable membrane proteins as key immunogenic components of $M$. arthritidis (Fig. 6) and the observation that they change in expression during in vivo passage (Fig. 2) are perhaps the most important outcomes of this study, indicating a role of these proteins as mediators of specific physical interactions with the host (Washburn et al., 1993) and as alternative targets providing avoidance of rapid destruction by the host immune system. In light of evidence for the occurrence of mycoplasma surface antigenic variation in vivo which has been previously reported for $M$. pulmonis (Talkington $e t$ al., 1989), M. bominis (Olson et al., 1991b), and more recently for M. gallisepticum (Levisohn et al., 1995), the finding of this and earlier studies (Washburn et al., 1992, 1995) that expression of major antigens of $M$. arthritidis strains changes during animal passages was not unexpected. Although not formally established here, recent preliminary results from our Hannover laboratory indicate that high-frequency surface antigenic variation of $M$. artbritidis does occur in vivo (Droesse et al., 1994). Whether this in vivo variation is accomplished by the occurrence of random variant clones or directed by the host immune response is currently being examined. These studies, combined with those related to the potential role of specific variant surface antigens in pathogenesis, will provide critical information in understanding the pathobiology of $M$. artbritidis and other mycoplasma species.

\section{ACKNOWLEDGEMENTS}

We thank Rosemarie Schmidt for her excellent technical assistance. This work was supported by the Sonderforschungsbereich 244 'Chronische Entzündung' of the Deutsche Forschungsgemeinschaft (H.K. and R.R.) and a predoctoral fellowship from the Studienstiftung des deutschen Volkes (M.D.).

\section{REFERENCES}

Behrens, A., Heller, M., Kirchhoff, H., Yogev, D. \& Rosengarten, R. (1994). A family of phase- and size-variant membrane surface lipoprotein antigens (Vsps) of Mycoplasma bovis. Infect Immun 62, 5075-5084.

Binder, A., Aumuller, R., Likitdecharote, B. \& Kirchhoff, H. (1990a). Isolation of Mycoplasma arthritidis from the joint fluid of boars. J Vet Med B 37, 611-614.
Binder, A., Gärtner, K., Hedrich, H. J., Hermanns, W., Kirchhoff, H. \& Wonigeit, K. (1990b). Strain differences in sensitivity of rats to Mycoplasma artbritidis ISR1 infection are under multiple gene control. Infect Immun 58, 1584-1590.

Blum, H., Beier, H. \& Gross, H. J. (1987). Improved silver staining of plant proteins, RNA and DNA in polyacrylamide gels. Electrophoresis 8, 93-99.

Boyer, M. J. \& Wise, K. S. (1989). Lipid-modified surface protein antigens expressing size variation within the species Mycoplasma byorbinis. Infect Immun 57, 245-254.

Bricker, T. M., Boyer, M. J., Keith, J., Watson-McKown, R. \& Wise, K. S. (1988). Association of lipids with integral membrane surface proteins of Mycoplasma byorbinis. Infect Immun 56, 295-301.

Cahill, J. F., Cole, B. C., Wiley, B. B. \& Ward, J. R. (1971). Role of biological mimicry in the pathogenesis of rat arthritis induced by Mycoplasma artbritidis. Infect Immun 3, 24-35.

Christiansen, G., Mathiesen, S. L., Nyvold, C. \& Birkelund, S. (1994). Analysis of a Mycoplasma hominis membrane protein, P120. FEMS Microbiol Lett 121, 121-128.

Cole, B. C. \& Griffiths, M. M. (1993). Triggering and exacerbation of autoimmune arthritis by the Mycoplasma arthritidis superantigen MAM. Artbritis Rbeum 36, 994-1002.

Cole, B. C. \& Ward, J. R. (1973). Mycoplasmas as arthritogenic agents. In The Mycoplasmas, vol. II, Human and Animal Mycoplasmas, pp. 367-398. Edited by J. G. Tully \& R. F. Whitcomb. New York: Academic Press.

Cole, B. C., Miller, M. L. \& Ward, J. R. (1967). A comparative study on the virulence of Mycoplasma arthritidis and 'Mycoplasma bominis, type 2' strains in rats. Proc Soc Exp Biol Med 124, 103-107.

Cole, B. C., Washburn, L. R. \& Taylor-Robinson, D. (1985a). Mycoplasma-induced arthritis. In The Mycoplasmas, vol. IV, Mycoplasma Pathogenicity, pp. 107-160. Edited by S. Razin \& M. F. Barile. New York: Academic Press.

Cole, B. C., Naot, Y., Stanbridge, E. J. \& Wise, K. S. (1985b). Interactions of mycoplasmas and their products with lymphoid cells in vitro. In The Mycoplasmas, vol. IV, Mycoplasma Pathogenicity, pp. 203-257. Edited by S. Razin \& M. F. Barile. New York: Academic Press.

Dallo, S. F., Chavoya, A. \& Baseman, J. B. (1990). Characterization of the gene for a 30-kilodalton adhesin-related protein of Mycoplasma pneumoniae. Infect Immun 58, 4163-4165.

Dienes, L. \& Madoff, S. (1953). Differences between oral and genital strains of human pleuropneumonia-like organisms. Proc Soc Exp Biol Med 82, 36-38.

Droesse, M., Tangen, G., Gummelt, I., Schmidt, R., Runge, M. \& Kirchhoff, H. (1994). Mycoplasma artbritidis surface antigen variation in vivo. In Abstracts of the 10th International Congress of the International Organization for Mycoplasmology (IOM). IOM Lett 3, 549-550.

Golightly-Rowland, L., Cole, B. C., Ward, J. R. \& Wiley, B. B. (1970). Effect of animal passage on arthritogenic and biological properties of Mycoplasma arthritidis. Infect Immun 1, 538-545.

Kirchhoff, H., Heitmann, J., Ammar, A., Hermanns, W. \& Schulz, L.-C. (1983a). Studies of polyarthritis caused by Mycoplasma artbritidis in rats. I. Detection of the persisting mycoplasma antigen by the enzyme immuno assay (EIA) and conventional culture technique. Zentralbl Bakt Orig A 254, 129-138.

Kirchhoff, H., Heitmann, J., Mielke, H., Dubenkropp, H. \& Schmidt, R. (1983b). Studies of polyarthritis caused by Mycoplasma artbritidis in rats. II. Serological investigation of rats experimentally infected with $M$. artbritidis ISR1. Zentralbl Bakt Orig $A$ 254, 275-280.

Kirchhoff, H., Heitmann, J., Dubenkropp, H. \& Schmidt, R. (1984). 
Antigenic cross-reactions between Mycoplasma artbritidis and rat tissues. Vet Microbiol 9, 237-248.

Kirchhoff, H., Binder, A., Runge, M., Meier, B., Jacobs, R. \& Busche, K. (1989). Pathogenetic mechanisms in the Mycoplasma artbritidis polyarthritis of rats. Rbeumatol Int 9, 193-196.

Krause, D. C. \& Taylor-Robinson, D. (1992). Mycoplasmas which infect humans. In Mycoplasmas: Molecular Biology and Patbogenesis, pp 417-444. Edited by J. Maniloff, R. N. McElhaney, L. R. Finch \& J. B. Baseman. Washington, DC: American Society for Microbiology.

Laber, G., Walzl, H. \& Schutze, E. (1975). Klinische und histopathologische Befunde bei der Mykoplasma-Polyarthritis der Ratte. I. Der Ablauf der Infektion in den ersten 8 Tagen. Zentralbl Bakt Orig A 230, 385-397.

Laemmli, U. K. (1970). Cleavage of structural proteins during the assembly of the head of bacteriophage T4. Nature 227, 680-685.

Levisohn, S., Rosengarten, R. \& Yogev, D. (1995). In vivo variation of Mycoplasma gallisepticum antigen expression in experimentally infected chickens. Vet Microbiol 45, 219-231.

Markham, P. F., Glew, M. D., Brandon, M: R., Walker, I. D. \& Whithear, K. G. (1992). Characterization of a major hemagglutinin protein from Mycoplasma gallisepticum. Infect Immun 60, 3885-3891.

Markham, P. F., Glew, M. D., Whithear, K. G. \& Walker, I. D. (1993). Molecular cloning of a member of the gene family that encodes pMGA, a hemagglutinin of Mycoplasma gallisepticum. Infect Immun 61, 903-909.

Markham, P. F., Glew, M. D., Sykes, J. E., Bowden, T. R., Pollocks, T. D., Browning, G. F., Whithear, K. G. \& Walker, I. D. (1994). The organisation of the multigene family which encodes the major cell surface protein, pMGA, of Mycoplasma gallisepticum. FEBS Lett 352, 347-352.

Morton, H. E. \& Roberts, R. J. (1967). Production of antimycoplasma (PPLO) antibodies in rabbits. Proc Soc Exp Biol Med 125, 538-543.

Olson, L. D., Shane, S. W., Karpas, A. A., Cunningham, T. M., Probst, P. S. \& Barile, M. F. (1991a). Monoclonal antibodies to surface antigens of a pathogenic Mycoplasma bominis strain. Infect Immun 59, 1683-1689.

Olson, L. D., Renshaw, C. A., Shane, S. W. \& Barile, M. F. (1991b). Successive synovial Mycoplasma bominis isolates exhibit apparent antigenic variation. Infect Immun 59, 3327-3329.

Preston, W. S. (1942). Arthritis in rats caused by pleuropneumonialike micro-organisms and the relationship of similar organisms to human rheumatism. J Infect Dis 70, 180-184.

Rosengarten, R. \& Wise, K. S. (1990). Phenotypic switching in mycoplasmas: phase variation of diverse surface lipoproteins. Science 247, 315-318.

Rosengarten, R. \& Wise, K. S.(1991). The Vlp system of Mycoplasma byorbinis: combinatorial expression of distinct size variant lipoproteins generating high-frequency surface antigenic variation. $J$ Bacteriol 173, 4782-4793.

Rosengarten, R., Behrens, A., Stetefeld, A., Heller, M., Ahrens, M., Sachse, K., Yogev, D. \& Kirchhoff, H. (1994). Antigen heterogeneity among isolates of Mycoplasma bovis is generated by high-frequency variation of diverse membrane surface proteins. Infect Immun 62, 5066-5074.

Simecka, J. W., Davis, J. K., Davidson, M. K., Ross, S. E., Stadtländer, C. T. K.-H. \& Cassell, G. H. (1992). Mycoplasma diseases of animals. In Mycoplasmas: Molecular Biology and Pathogenesis, pp. 391-415. Edited by J. Maniloff, R. N. McElhaney, L. R. Finch \& J. B. Baseman. Washington, DC: American Society for Microbiology.
Simmons, W., Cao, Z., Glass, J. I., Watson, H. L. \& Cassell, G. H. (1994). Comparison of the V-1 genes from two Mycoplasma pulmonis variants that differ with respect to disease potential. IOM Lett 3, 557-558.

Stadtlander, C. T. K.-H. \& Watson, H. L. (1992). Protein and antigen variability among strains of Mycoplasma artbritidis. Zentralbl Bakt 276, 407-417.

Talkington, D. F., Fallon, M. T., Watson, H. L., Thorp, R. K. \& Cassell, G. H. (1989). Mycoplasma pulmonis V-1 surface protein variation: occurrence in vivo and association with lung lesions. Microb Pathog 7, 429-436.

Tangen, G., Droesse, M., Struckmann-Möhrle, A., Körbis, M. \& Kirchhoff, H. (1994). Investigation of the structure and function of variable surface antigens of Mycoplasma artbritidis. IOM Lett 3, 577-578.

Teng, L.-J., Zheng, X., Glass, J. I., Watson, H. L., Tsai, J. \& Cassell, G. H. (1994). Ureaplasma urealyticum biovar specificity and diversity are encoded in multiple-banded antigen gene. J Clin Microbiol 32, 1464-1469.

Theiss, P. M., Kim, M. F. \& Wise, K. S (1993). Differential protein expression and surface presentation generate high-frequency antigenic variation in Mycoplasma fermentans. Infect Immun 61, 5123-5128.

Towbin, H., Staehelin, T. \& Gordon, J. (1979). Electrophoretic transfer of proteins from polyacrylamide gels to nitrocellulose sheets: procedure and some applications. Proc Natl Acad Sci US A 76, 4350-4354.

Tully, J. G. \& Whitcomb, R. F. (editors) (1979). The Mycoplasmas, vol. II, Human and Animal Mycoplasmas. New York: Academic Press.

Washburn, L. R. \& Hirsch, S. (1990). Comparison of four Mycoplasma arthritidis strains by enzyme immunoassay, metabolism inhibition, one- and two-dimensional electrophoresis, and immunoblotting. J Clin Microbiol 28, 1974-1981.

Washburn, L. R. \& Ramsey, J. R. (1989). Experimental induction of arthritis in LEW rats and antibody response to four Mycoplasma arthritidis strains. Vet Microbiol 21, 41-55.

Washburn, L. R., Ramsey, J. R. \& Roberts, L. K. (1985). Characterization of the metabolism inhibition antigen of Mycoplasma arthritidis. Infect Immun 49, 357-364.

Washburn, L. R., Ramsey, J. R. \& Andrews, M. B. (1988). Recognition of Mycoplasma artbritidis membrane antigens by rats and rabbits: comparison by immunoblotting and radioimmunoprecipitation. Vet Microbiol 17, 45--57.

Washburn, L. R., Voelker, L. L. \& Hirsch, S. (1992). Antigenic analysis of Mycoplasma artbritidis. In Abstracts of the 9th International Congress of the International Organization for Mycoplasmology (IOM). IOM Lett 2, 132.

Washburn, L. R., Hirsch, S. \& Voelker, L. L. (1993). Mechanisms of attachment of Mycoplasma arthritidis to host cells in vitro. Infect Immun 61, 2670-2680.

Washburn, L. R., Voelker, L. L., Ehle, J., Hirsch, S., Dutenhofer, C., Olson, K. \& Beck, B. (1995). Comparison of Mycoplasma artbritidis strains by enzyme-linked immunosorbent assay, immunoblotting, and DNA restriction analysis. J Clin Microbiol 33, 2271-2279.

Watson, H. L., McDaniel, L. S. Blalock, D. K. Fallon, M. T. \& Cassell, G. H. (1988). Heterogeneity among strains and a high rate of variation within strains of a major surface antigen of Mycoplasma pulmonis. Infect Immun 56, 1358-1363.

Watson, H. L., Blalock, D. K. \& Cassell, G. H. (1990). Variable antigens of Ureaplasma urealyticum containing both serovar-specific and serovar-cross-reactive epitopes. Infect Immun 58, 3679-3688. 
Watson, H. L., Zheng, X. \& Cassell, G. H. (1993). Structural variations and phenotypic switching of mycoplasmal antigens. Clin Infect Dis 17 (Suppl 1), S183-S186.

Wise, K. S. (1993). Adaptive surface variation in mycoplasmas. Trends Microbiol 1, 59-63.

Wise, K. S., \& Kim, M. F. (1987). Major membrane surface proteins of Mycoplasma byopneumoniae selectively modified by covalently bound lipid. J Bacteriol 169, 5546-5555.

Wise, K. S., Yogev, D. \& Rosengarten, R. (1992). Antigenic variation. In Mycoplasmas: Molecular Biology and Patbogenesis, pp. 473-489. Edited by J. Maniloff, R. N. McElhaney, L. R. Finch \& J. B. Baseman. Washington, DC: American Society for Microbiology.

Wise, K. S., Kim, M. F. Theiss, P. M. \& Lo, S.-C. (1993). A family of strain-variant surface lipoproteins of Mycoplasma fermentans. Infect Immun 61, 3327-3333.

Wu, H. (1987). Post-translational modification and processing of membrane proteins in bacteria. In Bacterial Outer Membranes as Model Systems, pp. 37-71. Edited by M. Inouye. New York: Wiley.

Yogev, D., Rosengarten, R., Watson-McKown, R. \& Wise, K. S. (1991). Molecular basis of Mycoplasma surface antigenic variation: a novel set of divergent genes undergo spontaneous mutation of periodic coding regions and $5^{\prime}$ regulatory sequences. EMBO J 10, 4069-4079.

Yogev, D., Menaker, D., Strutzberg, K., Levisohn, S., Kirchhoff, H., Hinz, K.-H. \& Rosengarten, R. (1994). A surface epitope undergoing high-frequency phase variation is shared by Mycoplasma gallisepticum and Mycoplasma bovis. Infect Immun 62, 4962-4968.

Zheng, X., Watson, H. L., Waites, K. B. \& Cassell, G. H. (1992). Serotype diversity and antigen variation among invasive isolates of Ureaplasma urealyticum from neonates. Infect Immun 60, 3472-3474.

Received 20 April 1995; revised 11 July 1995; accepted 3 August 1995. 